
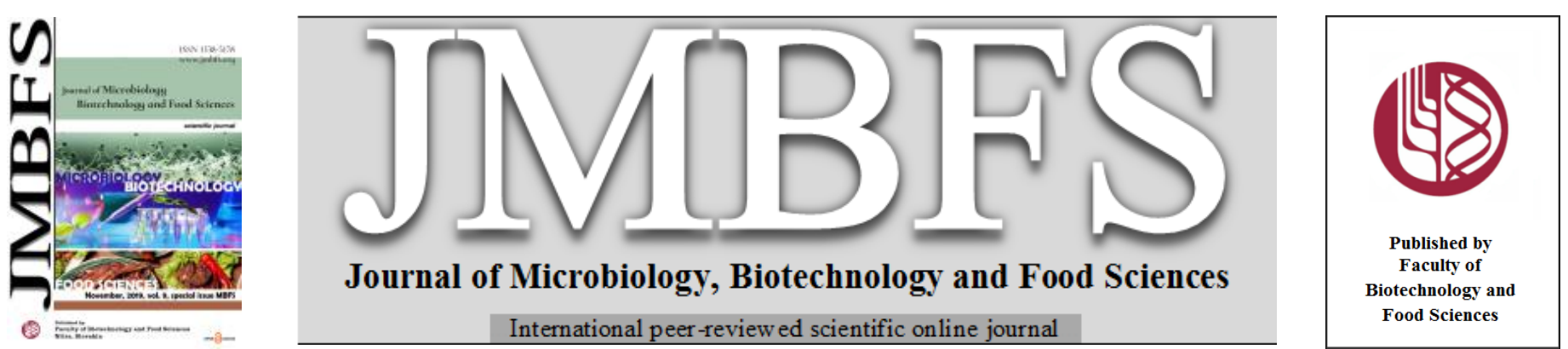

\title{
INHIBITORY EFFECT OF ESSENTIAL OILS FROM SOME LAURACEAE SPECIES ON THE GROWTH OF PENICILIUM COMMUNE
}

\author{
Denisa Foltinová ${ }^{1}$, Dana Tančinová*l, Miroslava Císarová ${ }^{2}$ \\ Address(es): prof. Ing. Dana Tančinová, PhD., \\ ${ }^{1}$ Slovak University of Agriculture, Faculty of Biotechnology and Food Sciences, Department of Microbiology, Tr. A. Hlinku 2, 94976 Nitra, Slovak republic. \\ ${ }^{2}$ University of SS. Cyril and Methodius, Department of Biology, Faculty of Natural Sciences, Nám. J. Herdu 2, SK-91701 Trnava, Slovak republic.
}

*Corresponding author: dana.tancinova@uniag.sk

doi: 10.15414/jmbfs.2019.9.special.385-389

\section{ARTICLE INFO}

Received 5. 9. 2019

Revised 16. 10. 2019

Accepted 22. 10. 2019

Published 8. 11. 2019

Regular article

open $\partial_{\text {ACCESS }}$

\begin{abstract}
The aim of this study was to determine the inhibitory effect of four essential oils (EOs) on the growth of seven strains of Penicillium commune isolated from moldy milk products by contact vapour. Next objective was to determine the minimum inhibitory doses (in vitro and probit analyses) of EOs, which at concentration $625 \mu 1.1^{-1}$ of air completely inhibited the growth of all strains. The antifungal activity was evaluated by the micro-atmosphere method. Cinnamon, cinnamon bark and litsea cubeba EOs completely inhibited the growth of strains during cultivation at $25^{\circ} \mathrm{C}$ and $5{ }^{\circ} \mathrm{C}$. Laurel $\mathrm{EO}$ had no effects on the growth of $P$. commune strains. EOs that completely inhibit the growth of all strains were used to determine their minimum inhibitory doses (MIDs). The best results were obtained for cinnamon EO (MIDs $15.625 \mu 1 . \mathrm{L}^{-1}$ of air) after all days at $25{ }^{\circ} \mathrm{C}$ of incubation. Litsea cubeba EO had the highest MIDs value (from 250 to $62,5 \mu 1.1^{-1}$ of air). It was found that EOs have different effects on individual strains of $P$. commune. The tested strains (KMi 370 and 402 ) showed differences among themselves even though they came from the same products (sour cream). According to probit analyses, the most effective tested EOs were cinnamon EO and the least effective was litsea cubeba EO. The antitoxinogenic effect of tested EOS was evaluated by TLC method. Also in this study, cinnamon EO was the most effective against CPA production by P. commune. This oil affected the production of CPA by strain KMi177 at $31.25 \mu 1.1^{-1}$ of air completely, and by strain KMi 403 , respectively.
\end{abstract}

Keywords: $P$. commune, essential oils, antifungal activity, vapor phase, cyclopiazonic acid

\section{INTRODUCTION}

Mould growth on cheese represents both a quality and a food safety problem and several moulds may destroy cheese. The genus Penicillium is the major contaminant followed by the genus Aspergillus (Kure and Skaar, 2019). Penicillium spp. is the predominant contaminant of dairy products (Hansen et al., 2003). It is because it's well-adapted to grow in the cheese matrix. The growth of molds in cheese is associated with undesirable taints and odors, liquefaction of the curd and in some cases, production of mycotoxins. P. commune (42\%) is one of the most widespread microscopic filamentous fungus from genus Penicillium, which is able to involved the degradation of cheese (Kure et al., 2001). Moreover, $P$. commune is able to produce cyklopiazonic acid. Some of the mycotoxins have been shown to be stable under normal processing conditions of cheese (Martín and Liras, 2017; Casquete et al., 2019). Natural preservatives have proven popularity such that interest continues in substituting chemical additives with natural. Therefore, production of safe food without or with low amounts of synthetic preservatives is one of the most important challenges in the food industry (Khorshidian et al., 2018). Essential oils (EOs) are mixtures of aromatic oily liquids extracted from different parts of plants, usually by steam distillation. Several of them are characterized by antibacterial and antifungal activities. This activity is depending on their constituents, mainly due to their content in terpenes and phenylpropanoids (Seow et al., 2014; Nikkhah et al., 2017). Several essentia oils can be applied as natural antimicrobial agents in order to inhibit microbial deterioration of cheeses and extending the shelf-life. Major compounds including thymol, carvacrol, eugenol, carvone and cinnamaldehyde are mainly responsible for exerting antimicrobial activity through various mechanisms such as increasing the cell permeability, change of membrane fatty acids and effect on membrane proteins. Few data are available about the application of EOs for their antifungal activity in food such as cheese. Despite of the suitable efficacy of essential oils in restriction of growth and survival of microorganisms in cheese, some limitations have been recognized in their application (Khorshidian et al., 2018). Essential oils constituents could be interacting with food components such as fat, carbohydrate and proteins. So their antimicrobial effect can be reduced, and this is the reason for use height concentration of EOs in food application. But EOs have intense aroma and their utilization at high concentrations in order to compensate their interaction with food components could result in sensory defects (Hyldgaard et al., 2012). In order to rectify this shortcoming, various approaches have been proposed. For these reasons, the aim of the presented study is to assess the antimycotic activity of some EOs against $P$. commune strains spoiling selected dairy products from Slovakia and evaluating their activity at lowest concentration by using Minimum inhibitory doses.

\section{MATERIAL AND METHODS}

\section{Eseential oils analysis}

The essential oils (EOs) used in this study were obtained from cinnamon (Cinnamomum zeylanicum L.), cinnamon bark (Cinnamomum zeylanicum L.), laurel (Laurus nobilis L.) and litsea cubeba (Litsea deccanensis L.) by hydrodistillation. The essential oils were supplied by Calendula company a.s. (Nová Lubovňa, Slovakia) and Hanus (Nitra, Slovakia). All EOs were stored in air-tight sealed glass bottles at $4^{\circ} \mathrm{C}$. Essential oils constituent were identified and the relatively composition of the oil was determined by gas chromatography followed by mass spectrometry (GC-MS) s described by Božik $\boldsymbol{e t}$ al. (2017). The identification of constituents was based on a comparison of their mass spectra and relative retention indices (RI) against the National Institute of Standards and Technology Library (NIST, USA), as well as authentic analytical standards and data from the literature. Relative proportions were calculated by dividing individual peak area by total area of all peaks. The response factor was not taken into account. Only compounds over $1 \%$ were included. Peaks under $1 \%$ were not counted. The used standards are listed in Table 2. 


\section{Fungal isolation and identification}

Seven isolates (Table 1) from different moldy milk products were used. Isolates of the genus Penicillium were identified to the species level according to morphological characteristics based on microscopy. To determine particular species, diagnostic literature was used as follows: Blakeslee (1915), Frisvad and Thrane (1995), Pitt and Hocking (2009), Samson et al., (2010). Isolates were inoculated in three points on the identification media CYA (Czapek Yeast Extract
Agar). MEA (Malt extract agar), YES (Yeast extract agar) and CREA (Creatine sucrose agar). Inoculated media were incubated at $25 \pm 1{ }^{\circ} \mathrm{C}, 7-17$ days in the dark After identification the strains belong to Penicillium commune were saved to the Collection of Fungi of Department of Microbiology; Faculty of Biotechnology and Food Sciences SUA in Nitra, Slovakia. For further analysis the 5 days old culture of Penicillium commune strains were used

Table 1 Origin of the strains Penicillium commune and identification media and temperature used

\begin{tabular}{lll}
\multicolumn{2}{l}{ Table 1 Origin of the strains Penicillium commune and identification media and temperature used } \\
\hline Strains & Origin & Cultivation temperature and identification media used \\
\hline$P$. commune KMi 177 & cheese flavored with pepper & \\
$P$. commune KMi 270 & smoked cheese (block) & CYA25: incubation period $7-14$ days in the dark at $25 \pm 1{ }^{\circ} \mathrm{C}$ \\
$P$. commune KMi 276 & smoked cheese (slices) & MEA: incubation period $7-14$ days in the dark at $25 \pm 1^{\circ} \mathrm{C}$ \\
$P$. commune KMi 277 & smoked cheese (slices) & CREA: incubation period $7-14$ days in the dark at $25 \pm 1{ }^{\circ} \mathrm{C}$ \\
$P$. commune KMi 370 & sour cream & YES: incubation period $7-14$ days in the dark at $25 \pm 1^{\circ} \mathrm{C}$ \\
$P$. commune KMi 402 & sour cream & \\
$P$. commune KMi 403 & parenica (pasta filata) & \\
\hline
\end{tabular}

\section{Antifungal activity of essential oils and minimum inhibitory doses (MIDs)}

The antifungal activity of tested EOs was evaluated by using the vapour phase of oils. The test was performed in sterile Petri dishes (PD) (Ø $90 \mathrm{~mm})$ for the first analysis and three sectors Petri dishes for the MIDs analysis. The PDs contained $15 \mathrm{~mL}$ of CYA. The used method was modified from Guynot et al. (2003) and is described in Císarová et al. (2016). Firstly EOs were tested in higher concentration $\left(625 \mu \mathrm{l} / \mathrm{L}^{-1}\right.$ of air). After preparation the PDs were tightly saled with parafilm and incubated for 14 days at $25 \pm 1^{\circ} \mathrm{C}$ and 35 days at $5 \pm 1^{\circ} \mathrm{C}$. The diameters (in $\mathrm{mm}$ ) of the growing colonies were measured at the $3^{\text {rd }}, 7^{\text {th }}, 11^{\text {th }}, 14^{\text {th }}$, $21^{\text {th }}, 28^{\text {th }}$ and $35^{\text {th }}$ day and strains incubated at $25 \pm 1^{\circ} \mathrm{C}$ were measured at $3^{\text {rd }}, 7^{\text {th }}$, $11^{\text {th }}, 14^{\text {th }}$ day with a digital caliper. After incubation, the minimum inhibitory doses (MIDs) of EOs with the most significant activity were recorded. EOs dissolved in DMSO were prepared at different concentrations $(500,250,125,62.5,31.25$ and 15.625). The used method and MIDs evaluation are described in Tančinová et al. (2019).For each fungal strain the inoculum was prepared. The spore suspension contained $10^{6}$ spore/.ml ${ }^{-1} .5 \mu$ of this suspension was inoculated on PDs with CYA medium. Cultivation was carried out at the $25 \pm 1^{\circ} \mathrm{C}$ and measured after $7^{\text {th }}$ and $14^{\text {th }}$ day.

\section{Anti-toxicogenic effect of essential oils}

The inhibitory of essential oils on the production of mycotoxins of tested strains was studied after 7 days of cultivation at $25^{\circ} \mathrm{C}$ on individual species treated by the gas diffusion method with EOs. The concentrations of EOs used depended on the activity of the concrete EO at the results from minimum inhibitory doses (MIDs). The range of 625 to $15.625 \mu 1.1^{-1}$ of air was used. We used only those samples of treated strains by EOs whose visible colony growth was not completely inhibited
We performed all analyses in three replicates by TLC method followed the methodology described in Císarová et al. (2015).

\section{Statistical analysis}

The antifungal effect of EOs at concentration $625 \mu 1.1^{-1}$ of air was performed in triplicate and the MIDs were performed in six repetitions. The results were expressed as the mean of the data obtained in each replicate. Statistical analyses were performed with descriptive statistics.

The ability of strains to grow in the presence of EO was coded to binomial scale (1 - growth observed, 0 - without growth). All data were processed by probit analysis in Statgraphics Centurion XVI (Statgraphics) software. Doses that inhibit the growth in $50 \%$ respectively $90 \%$ of cases $\left(\mathrm{MID}_{50}\right.$ and $\left.\mathrm{MID}_{90}\right)$ were reversely predicted from regression equation.

\section{RESULTS AND DISCUSSION}

\section{Chemical analysis of essential oils}

In this study, the antifungal properties of four essential oils from family Lauraceae were evaluated. Essential oils are a mixture of many complex compounds, which may vary depending on individual chemical compounds or their concentrations. Their antimicrobial activity also depends on their chemical composition (Omonijo et al., 2018). The most effective components of essential oils are predominantly terpenes, terpenoids and phenolic substances (Wiese $\boldsymbol{e t}$ al., 2018; Olmedo et al., 2018; Pichersky a Raguso, 2018). Based on the above we evaluated the chemical composition of tested EOs by the GC-MS analysis. The identified compounds of EOs are listed in Table 2.

Table 2 Essential oils - chemical composition (in \%) determined by gas chromatography coupled with mass spectrometry

\begin{tabular}{|c|c|c|c|c|c|}
\hline & Component & Cinnamon & Cinnamon bark & Laurel & Litsea cubeba \\
\hline 1 & $\alpha$-pinene ${ }^{a}$ & & & 5.4 & 1.5 \\
\hline 2 & $\beta$-phellandrene & & & 9.8 & 1.6 \\
\hline 3 & $\beta$-Pinene ${ }^{\mathrm{a}}$ & & & 4.0 & 1.1 \\
\hline 4 & p-Cymene & & & 2.2 & \\
\hline 5 & (R)-(+)-Limonene ${ }^{a}$ & & & & 14.6 \\
\hline 6 & 1,8-cineole ${ }^{\mathrm{a}}$ & & & 52.5 & 1.6 \\
\hline 7 & linalol $^{\mathrm{a}}$ & & 1.9 & & 1.1 \\
\hline 8 & mentol $^{\mathrm{a}}$ & & & 2.6 & \\
\hline 9 & $\alpha$-terpineol & & & 1.5 & \\
\hline 10 & asarone & & & & 1.0 \\
\hline 11 & Cinnamaldehyde $^{a}$ & 76.0 & 63.33 & & \\
\hline 12 & $\beta$-citrall & & & & 31.4 \\
\hline 13 & $\alpha$-citrall ${ }^{\mathrm{a}}$ & & & & 38.0 \\
\hline 14 & $\alpha$-terpineole acetate & & & 12.2 & \\
\hline 15 & Eugenol $^{\mathrm{a}}$ & & 20.0 & & \\
\hline 16 & $\beta$-caryophyllene ${ }^{a}$ & & 4.2 & 2.6 & 1 \\
\hline 17 & cumarine & 2.4 & & & \\
\hline 18 & Citronelyl propionate $^{a}$ & 4.2 & 1.6 & & \\
\hline 19 & o-methoxycinnamaldehyde & 11.6 & 2.2 & & \\
\hline \multicolumn{2}{|c|}{ total } & 94.8 & 94.9 & 96.9 & 96.0 \\
\hline
\end{tabular}

The major components according to the concrete essential oil were: cinnamon Cinnamaldehyde $(76.00 \%)$; cinnamon bark - Cinnamaldehyde $(63.3 \%)$ and Eugenol (20.00\%); laurel - Eucalyptol (52.5\%) and litsea cubeba - $\alpha$-citrall (38.00 $\%$ ) and limonene $(14.6 \%)$. Our results are similar with other authors (Lins et al., 2019; Wang et al., 2018; Fidan et al., 2019, Huang et al., 2019).

\section{Antifungal activity of essential oils}

The antifungal activity of four EOs against seven strains of $P$. commune was determined, using micro-atmosphere method, firstly at the concentration of 625 $\mu 1.1^{-1}$ of air. Three essential oils: cinnamon, cinnamon bark and litsea cubeba completely inhibited the growth of all strains during cultivation at $25^{\circ} \mathrm{C}$ and $5{ }^{\circ} \mathrm{C}$. Laurel essential oil had different effects on the growth of $P$. commune strains. 
Inhibitory effect of this EO on the growth of the all strains of $P$. commune during the cultivation period at $25 \pm 1{ }^{\circ} \mathrm{C}$ is showed in Figure $1 \mathrm{~A}$ and during the cultivation period at $5 \pm 1{ }^{\circ} \mathrm{C}$ is showed in Figure 1B.

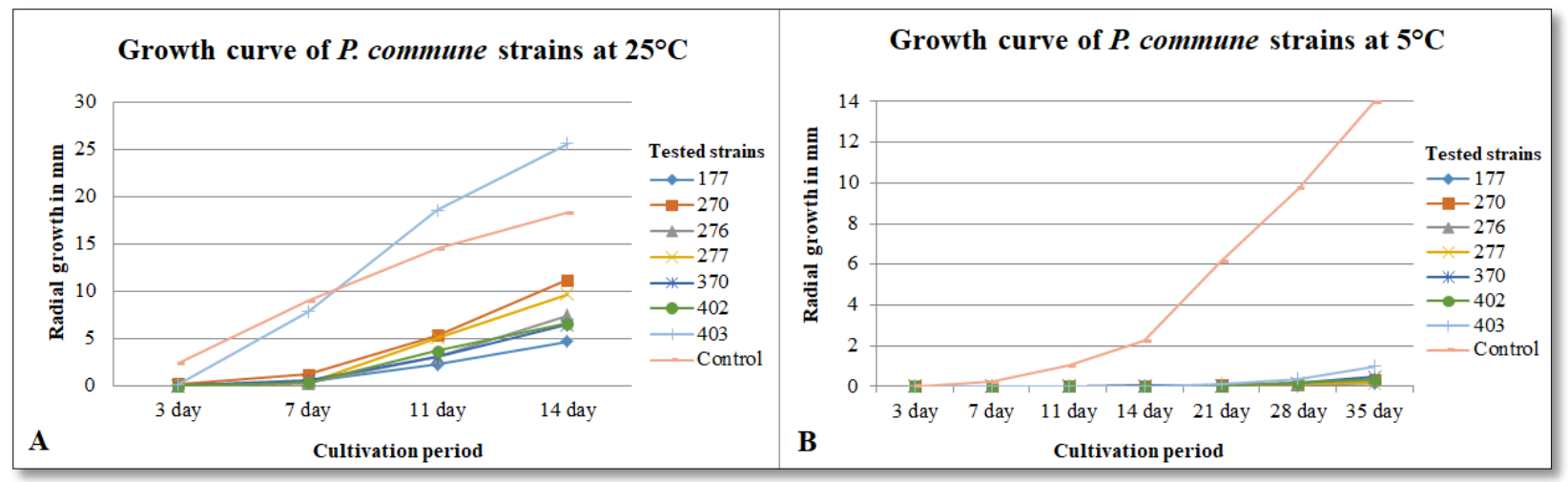

Figure 1 Growth of tested strains $P$. commune during the cultivation period at $25 \pm 1^{\circ} \mathrm{C}$ (A) and at $5 \pm 1{ }^{\circ} \mathrm{C}$ (B) under treatment by laurel $\mathrm{EO}$

The strain KMi 403 was the most resistant to antifungal effect of laurel EO at both, $25{ }^{\circ} \mathrm{C}$ after 14 days and at $5{ }^{\circ} \mathrm{C}$ after 35 days of cultivation. In addition its growth was after 14 days of cultivation at $25^{\circ} \mathrm{C}$ stimulating in compared with control set. The most sensitive strain was KMi 177 regardless of time of cultivation temperature. The laurel EO was able to inhibit its growth significantly. But is interesting, that this strain is obtained from a cheese flavored by pepper, due this fact it can be weakened. The similar result obtained Massa et al. (2018). They studied antifungal activity of some essential oils (included laurel EO) on growth of C. glabrata. The results showed that laurel EO had no inhibitory effect on the growth of this yeast. But authors Sevindik et al. (2019) tested essential oil from Laurel nobilis flowers and Laurel nobilis leaves by microdilution method against some strain of bacteria and yeast. Their results showed that those essential oils acted better against yeasts than against bacteria at relatively low concentrations (range between $0.097-3.125 \mu 1 / \mathrm{ml}^{-1}$ ).
It could be means that laurel can be able to inhibit growth of fungi but only in a contact with mycelium of tested strain.

\section{Evaluation of minimum inhibitory doses (MIDs)}

Three essential oils, concretely: cinnamon, cinnamom bark and litsea cubeba inhibited growth of tested strains completely at all temperatures $\left(25^{\circ} \mathrm{C}\right.$ and $\left.5{ }^{\circ} \mathrm{C}\right)$ during all days of cultivation. Therefore, lower concentrations (500-15.625 $\mu 1 . \mathrm{L}^{-1}$ of air) of these essential oils were used to determine the minimum inhibitory doses (MIDs) on the tested fungi. MIDs determined by the micro-atmosphere method are summarized in Table 3 .

Table 3 Minimum inhibitory doses ( $\mu 1 . \mathrm{L}^{-1}$ of air) of essential oils in vapor phase effective against the tested P. commune strains on CYA at $25^{\circ} \mathrm{C}$ after 7 and 14 days, respectively.

\begin{tabular}{|c|c|c|c|c|c|c|c|}
\hline \multirow{3}{*}{ Essential oils } & \multicolumn{7}{|c|}{ MIDs $\left(\mu 1 . \mathrm{L}^{-1}\right.$ of air) after 7 days of cultivation } \\
\hline & \multicolumn{7}{|c|}{ Tested strain number } \\
\hline & 177 & 270 & 276 & 277 & 370 & 402 & 403 \\
\hline Cinnamon & 62.5 & - & 31.25 & 62.5 & 62.5 & - & - \\
\hline Cinnamon bark & 62.5 & 31.25 & 31.25 & 62.5 & 62.5 & 31.25 & 31.5 \\
\hline \multirow[t]{4}{*}{ Litsea cubeba } & 125 & 125 & 62.5 & 125 & 125 & 250 & 250 \\
\hline & \multicolumn{7}{|c|}{ MIDs ( $\mu$ I.L $L^{-1}$ of air) after 14 days of cultivation } \\
\hline & \multicolumn{7}{|c|}{ Tested strain number } \\
\hline & 177 & 270 & 276 & 277 & 370 & 402 & 403 \\
\hline Cinnamon & 125 & 125 & 62.5 & 62.5 & 62.5 & - & - \\
\hline Cinnamon bark & 125 & 125 & 125 & 62.5 & 62.5 & 31.25 & 31.5 \\
\hline Litsea cubeba & 125 & 125 & 125 & 250 & 125 & 125 & 250 \\
\hline
\end{tabular}

The lowest MIDs against the tested Penicillium strains was found in cinnamon (MIDs 15.625 $\mu 1 . \mathrm{L}^{-1}$ of air) for three tested strains KMi 270, KMi 402 and KMi 403 after 7 days of cultivation and for strains KMi 402 and 403 after 14 days of cultivation at $25{ }^{\circ} \mathrm{C}$. Also Císarová et al. (2016) reported a relatively good effect of cinnamon essential oil. They found that cinnamon EO inhibited the growth of tested Aspergillus strains at MIDs in the range of $31.5 \mu 1 . \mathrm{L}^{-1}$ of air to $125 \mu 1 . \mathrm{L}^{-1}$ of air. Gómez et al. (2018) tested Origanum vulgare and Cinnamomum zeylanicum essential oils and their major active constituents, carvacrol and cinnamaldehyde, respectively, for inhibiting species of the genus Aspergillus and aflatoxin production in maize extract medium under different environmental conditions They reported that the effectiveness of EOs and their main constituents to inhibit fungal growth and aflatoxin production in contact assays was lower than in vapour phase assays.

In our study, the lowest effective essential oil was litsea cubeba with the higher MIDs for four tested strains - for 2 strains (KMi 402 and 403) after 7 days of cultivation and for 2 strains (KMi 277 and 403) after 14 days of cultivation with MIDs value $250 \mu 1 . \mathrm{L}^{-1}$ of air. But many authors described Litsea cubeba EOs like the very potent antifungal and antibacterial agents (Li et al., 2016; Hu et al., 2019) Using probit analysis, predicted $\mathrm{MIDs}_{90}$ and $\mathrm{MIDs}_{50}$ were calculated. The MID values were calculated only for those essential oils that did not inhibit growth of the tested strains of $P$. commune completely at reduced concentrations (500-15.625 $\mu 1 . \mathrm{L}^{-1}$ of air). The results are shown in Table 4.

The most effective tested essential oils were cinnamon and cinnamon bark EOs, less effective litsea cubeba EO. The highest MID $_{90}\left(162.29 \mu 1 . \mathrm{L}^{-1}\right.$ of air) was determinate for litsea cubeba against strains KMi 277 after 14 days of cultivation. Also the highest $\mathrm{MID}_{50}\left(150.53 \mu 1 . \mathrm{L}^{-1}\right.$ of air) was determinate for litsea cubeba, but against strains KMi 403 after 7 days of cultivation. All results obtained were statistically significant $(p<0.005)$, except MIDs values for litsea cubeba EO against strain KMi 370 ( $p$ 0.348) after 7 and 14 days of cultivation.

\section{Inhibitory effect of EOs on CPA production}

All strains of $P$. commune were tested in vitro for the production of cyclopiazonic acid (CPA) by TLC method. Production of CPA was confirmed for four strains (KMi 177, 277, 370 and 403). Anti-toxinogenic effect was determined in 4 EOs, which did not inhibit the growth of the tested isolates completely at the different concentration. The used concentration was selected according the results from MIDs evaluation. The results are summarized in Table 5.

The anti-toxinogenic potential of essential oils has been already demonstrated in previous studies (Císarová et al., 2015; Císarová et al., 2016; Foltinova et al., 2017).Treatments with cinnamon $E O$ showed some potential of fungal toxic inhibition. This oil affected the production of CPA by strain KMi177 at $31.25 \mu 1.1$ ${ }^{1}$ of air completely, and by strain KMi 403, respectively. Production of CPA by strains KMi 370 was completely inhibited by this oil at all tested concertation $\left(31.25-15.625 \mu 1.1^{-1}\right)$. Cinnamon bark EO was able to inhibited production of CPA completely only in strain KMi 403 at the concentration $31.25 \mu 1.1^{-1}$ of air. Litsea cubeba had very low effect on the production of CPA by tested strains. Laurel was the least effective EO because its inhibitory effect on the growth of tested strains was not detected even at the highest concentration $\left(625 \mu 1.1^{-1}\right.$ of air), as so as antitoxinogenic activity.

The strains used in our study were isolated directly from the moldy dairy products from Slovakia. For the use of EOs in food matrix, it is necessary to use very low concentrations, in order to not negatively affect the organoleptic properties of food, especially dairy products. Therefore, it is necessary to test essential oils directly on 
food. Although essential oils are not always able to inhibit fungal growth at low concentrations completely, they could be used in foods to inhibit their toxic metabolites.

Table 4 The minimum inhibitory doses $\left(\mathrm{MID}_{50}\right.$ and $\left.\mathrm{MID}_{90}\right)$ of tested essential oils expressed as $\mu 1 . \mathrm{L}^{-1}$ of air of air estimated by probit analyses for tested strains of $P$. commune

\begin{tabular}{|c|c|c|c|c|c|c|c|}
\hline \multirow{2}{*}{ Strains } & \multirow{2}{*}{ MIDs } & \multicolumn{2}{|c|}{ Cinnamon } & \multicolumn{2}{|c|}{ Cinnamon bark } & \multicolumn{2}{|c|}{ Litsea cubeba } \\
\hline & & 7 days & 14 days & 7 days & 14 days & 7 days & 14 days \\
\hline \multirow{2}{*}{ KMi177 } & MID $_{50}$ & 27.53 & 21.88 & 27.53 & 21.88 & 66.50 & 66.50 \\
\hline & MID $_{90}$ & 32.73 & 52.56 & 32.73 & 52.56 & 78.94 & 78.94 \\
\hline$p$ Value & & 0.000 & & 0.000 & & 0.000 & \\
\hline \multirow{2}{*}{ KMi 270} & MID $_{50}$ & nd & nd & 13.3 & 13.3 & 56.12 & 66.50 \\
\hline & MID $_{90}$ & nd & nd & 20.98 & 20.98 & 64.97 & 78.94 \\
\hline$p$ Value & & $n d$ & & 0.005 & & 0.000 & \\
\hline \multirow{2}{*}{ KMi 276} & MID $_{50}$ & 13.4 & 18.21 & 13.4 & 140.63 & nd & 66.50 \\
\hline & MID $_{90}$ & 20.98 & 45.68 & 20.98 & 162.29 & nd & 78.94 \\
\hline$p$ Value & & 0.000 & & 0.000 & & 0.000 & \\
\hline \multirow{2}{*}{ KMi 277} & MID $_{50}$ & 15.87 & 18.21 & 15.87 & 18.21 & nd & 140.63 \\
\hline & MID $_{90}$ & 36.49 & 45.68 & 36.49 & 45.68 & nd & 162.29 \\
\hline$p$ Value & & 0.000 & & 0.000 & & 0.000 & \\
\hline \multirow{2}{*}{ KMi 370} & MID $_{50}$ & nd & nd & nd & nd & 58.03 & 58.03 \\
\hline & MID $_{90}$ & 34.25 & 34.25 & 34.25 & 34.25 & 64.23 & 64.23 \\
\hline$p$ Value & & 0.041 & & 0.041 & & 0.348 & \\
\hline \multirow{2}{*}{ KMi 402} & MID $_{50}$ & nd & nd & 13.4 & 18.21 & 119.80 & 119.80 \\
\hline & MID $_{90}$ & nd & nd & 20.98 & 45.68 & 135.99 & 135.99 \\
\hline$p$ Value & & $n d$ & & 0.000 & & 0.000 & \\
\hline \multirow{2}{*}{ KMi 403} & MID $_{50}$ & nd & nd & 13.4 & 18.21 & 131.21 & 94.47 \\
\hline & MID $_{90}$ & nd & nd & 20.98 & 45.68 & 150.53 & 104.73 \\
\hline$p$ Value & & nd & & 0.000 & & 0.000 & \\
\hline
\end{tabular}

Legend: nd-MID not determined

Table 5 Inhibitory effect of tested EOs at different concentrations on CPA production by tested strains of $P$. commune

\begin{tabular}{|c|c|c|c|c|c|}
\hline Essential oils & Tested concentration $\left(\mu \mathrm{l} . \mathrm{l}^{-1}\right.$ of air $)$ & \multicolumn{4}{|c|}{ Tested strain number } \\
\hline Cinnamon & 15.625 & $3 * / 1^{\mathrm{n}}$ & $3 / 3$ & $3 / 0$ & - \\
\hline \multirow{2}{*}{ Cinnamon bark } & 15.625 & $3 / 3$ & $3 / 3$ & $3 / 2$ & $3 / 1$ \\
\hline & 31.25 & $3 / 3$ & $3 / 3$ & $3 / 1$ & $3 / 0$ \\
\hline \multirow{3}{*}{ Litsea cubeba } & 15.625 & $3 / 3$ & $3 / 3$ & $3 / 3$ & $3 / 3$ \\
\hline & 62.5 & $3 / 1$ & $3 / 3$ & $3 / 2$ & $3 / 2$ \\
\hline & 125 & - & - & - & $3 / 1$ \\
\hline Laurel & 625 & $3 / 3$ & $3 / 3$ & $3 / 3$ & $3 / 3$ \\
\hline
\end{tabular}

Legend: $*$ - repetition tested, ${ }^{\mathrm{n}}$ - number of positive production

\section{CONCLUSION}

In this study, the inhibitory effect of selected essential oils cinnamon (Cinnamomum zeylanicum L.), cinnamon bark (Cinnamomum zeylanicum L.) laurel (Laurus nobilis L.) and litsea cubeba (Litsea deccanensis L.) on the growth of $P$. commune strains ( 7 strains) was evaluated. Our results showed that cinnamon, cinnamon bark and litsea cubeba EO had a 100\% inhibition effect on the growth of all tested strains at the higher concentration $\left(625 \mu 1 . \mathrm{L}^{-1}\right.$ of air) throughout the cultivation days. Laurel EO had no effect on the growth of tested strains. The MIDs assay confirmed the most significant efficacy of the two oils, namely cinnamon and cinnamon bark. Litsea cubeba had no significant effect. Is interestingly, the tested strains (KMi 370 and 402) showed differences among themselves even though they came from the same products (sour cream). Strain KMi 402 was much more sensitive to essential oils than strain KMi 370. We also achieved the same results in testing the potential ability of essential oils to inhibit mycotoxin production, where cinnamon was the most effective and laurel had no effect on CPA production. Our findings confirm that although essential oils are not able to inhibit fungal growth at the lowest concentrations, they are capable of inhibiting mycotoxins production. Essential oils can be used in agro industries instead of synthetic pesticides or preservatives, to control plant diseases causing severe destruction to crops and they can be proposed as potential antimicrobial agents for food commodity preservation in the near future.

Acknowledgments: This work was supported by APVV-15-0543, KEGA 015SPU-4/2018 and Research Center AgroBioTech.The authors thank Eva Sádovská for her responsible approach in the preparation and realization of the experiment.

\section{REFERENCES}

BLAKESLEE, A. F. 1915. Linder's roll tube method of separating cultures Phythopathology, 5, 68-69. https://doi.org/10.5962/bhl.title.109120

BOŽIK, M., CÍSAROVÁ, M., TANČINOVÁ, D., KOUŘIMSKÁ, L., HLEBA, L. \& KLOUČEK, P. 2017. Selected essential oil vapours inhibit growth of Aspergillus spp. in oats with improved consumer acceptability. Industrial crops and products, 98, 146-152. https://doi.org/10.1016/j.indcrop.2016.11.044

CASQUETE, R., BENITO, M. J., ARANDA, E., MARTÍN, A., HERNÁNDEZ, A., DE GUÍA CÓRDOBA, M. 2019. Cyclopiazonic acid gene expression as strategy to minimizing mycotoxin contamination in cheese. Fungal Biology. https://doi.org/10.1016/j.funbio.2019.06.011

CÍSAROVÁ, M., TANČINOVÁ, D., BRODOVÁ, M. 2015. The inhibitory effect of essential oils on the growth of genus Penicillium isolated from peanuts by contact vapor. Journal of Microbiology, Biotechnology \& Food Sciences, 4(1), 611. https://doi.org/10.15414/jmbfs.2014.4.special1.6-11

CÍSAROVÁ, M., TANČINOVÁ, D., MEDO, J., KAČÁNIOVÁ, M. 2016. The in vitro effect of selected essential oils on the growth and mycotoxin production of Aspergillus species. Journal of Environmental Science and Health, Part B, 51(10), 668-674. https://doi.org/10.1080/03601234.2016.1191887

FIDAN, H., STEFANOVA, G., KOSTOVA, I., STANKOV, S., DAMYANOVA, S., STOYANOVA, A., ZHELJAZKOV, V. D. 2019. Chemical Composition and Antimicrobial Activityof Laurus nobilis L. Essential Oils from Bulgaria Molecules, 24(4), 804. https://doi.org/10.3390/molecules24040804

FOLTINOVÁ, D., TANČINOVÁ, D., CÍSAROVÁ, M. 2017. Influence of essential oils on the growth of Aspergillus flavus. Potravinárstvo: Slovak Journal of Food Sciences, 11(1), 322-331. https://doi.org/10.5219/725 
FRISVAD, J. C., THRANE, U. 1995. Filamentous fungi in foods and feeds: ecology, spoilage and mycotoxins production. Handbookof applied mycology, 3, 31-68.

GÓMEZ, J. V., TARAZONA, A., MATEO-CASTRO, R., GIMENOADELANTADO, J. V., JIMÉNEZ, M., MATEO, E. M. 2018. Selected plant essential oils and their main active components, a promising approach to inhibit aflatoxigenic fungi and aflatoxin production in food. Food Additives \& Contaminants, 35(8),

1581-1595. https://doi.org/10.1080/19440049.2017.1419287

GUYNOT, M. E., RAMOS, A. J., SETO, L., PURROY, P., SANCHIS, V. MARIN, S. 2003. Antifungal activity of volatile compounds generated by essential oils against fungi commonly causing deterioration of bakery products. Journal of Applied Microbiology, 94(5), 893-899. https://doi.org/10.1046/j.13652672.2003.01927.x PMid:12694455

HANSEN, M. E., LUND, F., CARSTENSEN, J. M. 2003. Visual clone identification of Penicillium commune isolates. Journal of Microbiological Methods, 52(2), 221-229. https://doi.org/10.1016/s0167-7012(02)00160-4

HU, W., LI, C., DAI, J., CUI, H., \& LIN, L. 2019. Antibacterial activity and mechanism of Litsea cubeba essential oil against methicillin-resistan Staphylococcus aureus (MRSA). Industrial Crops and Products, 130, 34-41. https://doi.org/10.1016/j.indcrop.2018.12.078

HUANG, H., CHEN, R., MA, H., YUAN, Z. 2019. Quality attributes and chemica composition of commercial cinnamon oils. Quality Assurance and Safety of Crops \& Foods, 11(1), 89-94. https://doi.org/10.3920/qas2018.1348

HYLDGAARD, M., MYGIND, T., MEYER, R. L. 2012. Essential oils in food preservation: mode of action, synergies, and interactions with food matrix components. Frontiers in microbiology, 3 ,

https://doi.org/10.3389/fmicb.2012.00012

KHAN, A., AHMAD, A., AKHTAR, F., YOUSOUF, S., XESS, I., KHAN, L. A. MANZOOR, N. 2010. Ocimum sanctum essential oil and its active principles exert their antifungal activity by disrupting ergosterol biosynthesis and membrane integrity. Research in Microbiology. 161, 816-823. https://doi.org/10.1016/j.resmic.2010.09.008

KHORSHIDIAN, N., YOUSEFI, M., KHANNIRI, E., MORTAZAVIAN, A. M 2018. Potential application of essential oils as antimicrobial preservatives in cheese. Innovative Food Science \& Emerging Technologies, 45, 62-72. https://doi.org/10.1016/j.ifset.2017.09.020

KURE, C. F., SKAAR, I. 2019. The fungal problem in cheese industry. Current Opinion in Food Science. 29, 14. https://doi.org/10.1016/j.cofs.2019.07.003

KURE, C. F., WASTESON, Y., BRENDEHAUG, J., \& SKAAR, I. 2001. Mould contaminants on Jarlsberg and Norvegia cheese blocks from four factories. International Journal of Food Microbiology,70(1-2), 21-27. https://doi.org/10.1016/s0168-1605(01)00520-7

LI, Y., KONG, W., LI, M., LIU, H., ZHAO, X., YANG, S., YANG, M. 2016 Litsea cubeba essential oil as the potential natural fumigant: inhibition of Aspergillus flavus and $\mathrm{AFB}_{1}$ production in licorice. Industrial Crops and Products, 80, 186-193. https://doi.org/10.1016/j.indcrop.2015.11.008

LINS, L., DAL MASO, S., FONCOUX, B., KAMILI, A., LAURIN, Y., GENVA, M., DELEU, M. 2019. Insights into the Relationships Between Herbicide Activities, Molecular Structure and Membrane Interaction of Cinnamon and Citronella Essential Oils Components. International journal of molecular sciences, 20(16), 4007. https://doi.org/10.3390/ijms20164007

MARTÍN, J. F., LIRAS, P. 2016. Secondary metabolites in cheese fungi. Fungal Metabolites, 1-23. https://doi.org/10.1007/978-3-319-19456-1_37-1

MASSA, N., CANTAMESSA, S., NOVELLO, G., RANZATO, E. MARTINOTTI, S., PAVAN, M., BONA, E. 2018. Antifungal activity of essential oils against azole-resistant and azole-susceptible vaginal Candida glabrata strains Canadian journal of microbiology, 64(10), 647-663. https://doi.org/10.1139/cjm2018-0082

NIKKHAH, M., HASHEMI, M., HABIBI NAJAFI, M.,B., FARHOOSH, R. 2017. Synergistic effects of some essential oils against fungal spoilage on pear fruit International Journal of Food Microbiology. 18, 285-294. https://doi.org/10.1016/j.ijfoodmicro.2017.06.021

OLMEDO, R., RIBOTTA, P., GROSSO, N. R. 2018. Antioxidant Activity of Essential Oils Extracted from Aloysia triphylla and Minthostachys mollis that Improve the Oxidative Stability of Sunflower Oil under Accelerated Storage Conditions. European journal of lipid science and technology, 120(8), 1700374. https://doi.org/10.1002/ejlt.201700374

OMONIJO, F. A., NI, L., GONG, J., WANG, Q., LAHAYE, L., \& YANG, C. 2018. Essential oils as alternatives to antibiotics in swine production. Animal Nutrition, 4(2), 126-136. https://doi.org/10.1016/j.aninu.2017.09.001

PICHERSKY, E., RAGUSO, R. A. 2018. Why do plants produce so many terpenoid compounds. New Phytologist, 220(3), 692-702. https://doi.org/10.1111/nph.14178

PITT, J. I., HOCKING, A. D. 2009. Fungi and food spoilage. $3^{\text {rd }}$ ed. London, New York : Springer Science \& Business Media, LLC, 519. ISBN 978-0-387-92206-5. https://doi.org/10.1007/978-0-387-92207-2
SAMSON, R. A., HOUBRAKEN, U., THRANE, U., FRISVAD, J. C., ANDERSEN, B. 2010. Food and Indoor Fungi. Utrecht, Netherlands : CBSKNAW Fungal Biodiversity Centre, 390 p. ISBN 978-90-70351-82-3.

SEOW, Y.X., YEO, C., CHUNG, H. L., YUK, H. G. 2014. Plant Essential Oils as Active Antimicrobial Agents. Critical Reviews in Food Science and Nutrition, 54, 625-644. https://doi.org/10.1080/10408398.2011.599504

SEVINDIK, E., AYDIN, S., OKAN, K., EFE, F. 2018. Antibacterial Activity of Essential Oils from Laurus nobilis L. Flowers and Leaves Grown in the West Anatolian Area. Fresenius Environmental Bulletin, 28(9), 6555-6559. https://doi.org/10.1080/0972060x.2018.1505556

TANČINOVÁ, D., MEDO, J., MAŠKOVÁ, Z., FOLTINOVÁ, D., \& ÁRVAY, J. 2019. Effect of essential oils of Lamiaceae plants on the Penicillium commune. The Journal of Microbiology, Biotechnology and Food Sciences, 8(4), 1111. https://doi.org/10.15414/jmbfs.2019.8.4.1111-1117

WANG, Y., ZHANG, Y., SHI, Y. Q., PAN, X. H., LU, Y. H., CAO, P. 2018 Antibacterial effects of cinnamon (Cinnamomum zeylanicum) bark essential oil on Porphyromonas gingivalis. Microbial pathogenesis, 116, 26-32. https://doi.org/10.1016/j.micpath.2018.01.009

WIESE, N., FISCHER, J., HEIDLER, J., LEWKOWSKI, O., DEGENHARDT, J. ERLER, S. 2018. The terpenes of leaves, pollen, and nectar of thyme (Thymus vulgaris) inhibit growth of bee disease-associated microbes. Scientific reports 8(1), 14634. https://doi.org/10.1038/s41598-018-32849-6 